\title{
EFFECT OF HYPOXIA ON THE EXPRESSION OF NUCLEAR GENES ENCODING MITOCHONDRIAL PROTEINS IN U87 GLIOMA CELLS
}

\author{
O. H. MINCHENKO', O. O. RIABOVOL ${ }^{1}$, D. O. TSYMBAL ${ }^{1}$, \\ D. O. MINCHENKO ${ }^{1,2}$, O. O. RATUSHNA \\ ${ }^{1}$ Palladin Institute of Biochemistry, National Academy of Sciences of Ukraine, Kyiv; \\ e-mail: ominchenko@yahoo.com; \\ ${ }^{2}$ Bohomolets National Medical University, Kyiv, Ukraine
}

We have studied the effect of hypoxia on the expression of nuclear genes encoding mitochondrial proteins in U87 glioma cells under the inhibition of IRE1 (inositol requiring enzyme-1), which controls cell proliferation and tumor growth as a central mediator of endoplasmic reticulum stress. It was shown that hypoxia down-regulated gene expression of malate dehydrogenase 2 (MDH2), malic enzyme 2 (ME2), mitochondrial aspartate aminotransferase (GOT2), and subunit B of succinate dehydrogenase (SDHB) in control (transfected by empty vector) glioma cells in a gene specific manner. At the same time, the expression level of mitochondrial $N A D P^{+}$-dependent isocitrate dehydrogenase 2 (IDH2) and subunit D of succinate dehydrogenase (SDHD) genes in these cells does not significantly change in hypoxic conditions. It was also shown that the inhibition of IRE1 signaling enzyme function in U87 glioma cells decreases the effect of hypoxia on the expression of ME2, GOT2, and SDHB genes and introduces the sensitivity of IDH2 gene to hypoxia. Furthermore, the expression of all studied genes depends on IRE1-mediated endoplasmic reticulum stress signaling in gene specific manner, because IRE1 knockdown significantly decreases their expression in normoxic conditions, except for IDH2 gene, which expression level is strongly up-regulated. Therefore, changes in the expression level of nuclear genes encoding ME2, MDH2, IDH2, SDHB, SDHD, and GOT2 proteins possibly reflect metabolic reprogramming of mitochondria by hypoxia and IRE1-mediated endoplasmic reticulum stress signaling and correlate with suppression of glioma cell proliferation under inhibition of the IREI enzyme function.

Key words: hypoxia, mRNA expression, mitochondrial proteins, IRE1 inhibition, U87 glioma cells.

$\mathrm{M}$ itochondria play an important role in the regulation of tumor growth and apoptosis through numerous metabolic pathways [1-3]. The functional activity of mitochondria is controlled through numerous nuclear-encoded mitochondrial proteins, and most of these factors and enzymes are responsible for metabolic reprogramming of mitochondria in cancer as well as in other diseases [4-7]. Therefore, the level of mitochondria associated apoptosis inducing factor 1 (AIFM1) is significantly higher in carcinomas than in normal tissues [2]. Hypoxia as an obligate factor of tumor growth affects the expression of some nuclear genes encoding mitochondrial factors and enzymes $[5,8$, 9]. Thus, expression of ENDOG (endonuclease G), $P O L G$ (DNA directed polymerase gamma), TSFM (Ts mitochondrial translational elongation factor), and MTIF2 (mitochondrial translational initiation factor 2) genes encoding mitochondrial proteins, which are related to the control of mitochondrial genome function as well as to cell proliferation, is affected by hypoxia in different ways [3, 5, 6]. Furthermore, ENDOG regulates an integral network of apoptotic endonucleases, which appear to act simultaneously before cell death by destroying the host cell DNA [3, 10]. Endoplasmic reticulum stress is a necessary growth component of malignant tumors, including malignant gliomas, which are highly aggressive tumors, and inhibition of IRE1 (inositol requiring enzyme 1) which represents a dominant signaling pathway of the unfolded protein response significantly decreases the glioma growth [11-15]. Previously it was shown that inhibition of IRE1 (inositol requiring enzyme 1) which represents a dominant signaling pathway of the unfolded protein response, modifies hypoxic regulation of ENDOG, $P O L G, T S F M$, and MTIF2 genes expression [5].

Mitochondrial NAD-dependent malic enzyme (ME2) that catalyzes the oxidative decarboxylation of malate to pyruvate is a target of TP53 depletion 
of this enzyme, induces erythroid differentiation in human erythroleukemia cells [16, 17]. Moreover, malic enzyme 2 is highly expressed in many solid tumors and its knockdown inhibits cell proliferation and induces cell death as well as suppresses lung tumor growth in vivo [18]. Recently it was shown that embonic acid, a natural compound, can specifically inhibit the enzymatic activity of mitochondrial $\mathrm{NADP}^{+}$-dependent malic enzyme and induce cellular senescence [19]. The malate-aspartate shuttle is indispensable for the net transfer of cytosolic NADH into mitochondria to maintain a high rate of glycolysis and to support rapid tumor cell growth [20]. It is done by two pairs of enzymes that localize to the mitochondria and cytoplasm, glutamate oxaloacetate transaminases (GOT), and malate dehydrogenases (MDH). Acetylation of mitochondrial GOT2 enhances the association between GOT2 and MDH2 and promotes the net transfer of cytosolic NADH into mitochondria and changes the mitochondrial NADH/NAD ${ }^{+}$redox state to support ATP production. Moreover, GOT2 acetylation promotes proliferation of the pancreatic cell and tumor growth in vivo [20]. It was recently shown that LW6, the inhibitor of MDH2, reduces cell proliferation and apoptosis [21].

The mitochondrial $\mathrm{NADP}^{+}$-dependent isocitrate dehydrogenase (IDH2) catalyzes the conversion of isocitrate to $\alpha$-ketoglutarate and concomitantly produces reduced NADPH from $\mathrm{NADP}^{+}$. Mutations in the genes encoding IDH1 and IDH2 have recently been found in a variety of human cancers, most commonly in glioma, acute myeloid leukemia [22]. The expression of mutant IDH impairs cellular differentiation in various cell lineages and promotes tumor development jointly with other cancer genes [22, 23]. Moreover, IDH2 mutations promote glioma genesis by disrupting chromosomal topology and allowing aberrant regulatory interactions that induce oncogene expression [23]. Recently it was shown that IDH2 plays an essential role in protecting cells against oxidative stress-induced damage and this enzyme deficiency leads to mitochondrial dysfunction and production of reactive oxygen species in cancer cells [24].

Succinate dehydrogenase (SDH) complex is specifically involved in the oxidation of succinate, carries electrons from FADH to CoQ and is composed of four subunits. The iron-sulfur subunit (SDHB) is highly conserved and contains three cysteine-rich clusters which may comprise the iron- sulfur centers of the enzyme [25]. The oncogenic role of this enzyme complex has only recently been recognized and the complex is currently considered an important oncogenic signaling pathway with tumor suppressor properties [26, 27]. SDHB, as a central core subunit, is responsible for the integrity of the SDH complex, the expression of SDHB is lost in all SDH-deficient neoplasms irrespective of the specific SDH subunit affected by a genetic mutation in addition to concurrent loss of the subunit specifically affected by genetic alteration [25, 28].

Malignant gliomas are highly aggressive tumors with very poor prognosis, and to date there is no efficient treatment available. The moderate efficacy of conventional clinical approaches therefore underlines the need for new therapeutic strategies. Hypoxia is associated to glioma development and locally induces an adaptive response which confers to tumor cells an enhanced survival and a more agressive behaviour. A better knowledge of tumor responses to hypoxia is required to elaborate therapeutical strategies of cell sensibilization based on the blockade of survival mechanisms [9, 29].

The aim of this study was investigation of the effect of hypoxia on the expression of $M E 2, M D H 2$, $I D H 2, S D H B, S D H D$, and GOT2 genes, which related to cell proliferation and apoptosis, in glioma cells in relation to inhibition of signaling enzyme IRE1.

\section{Materials and Methods}

Cell Lines and Culture Conditions. In this study we used two sublines of U87 glioma cells, which are growing in high glucose (4.5 g/l) Dulbecco's modified Eagle's minimum essential medium (DMEM; Gibco, Invitrogen, USA) supplemented with glutamine (2 mM), 10\% fetal bovine serum (EquitechBio, Inc., USA), streptomycin $(0.1 \mathrm{mg} / \mathrm{ml}$; Gibco) and penicillin (100 units $/ \mathrm{ml}$; Gibco) at $37^{\circ} \mathrm{C}$ in a $5 \%$ $\mathrm{CO}_{2}$ incubator. One subline was obtained by selection of stable transfected clones with overexpression of vector (pcDNA3.1), which was used for creation of dominant-negative constructs (dnIRE1). This untreated subline of glioma cells (control glioma cells) was used as control 1 in the study of hypoxia effects on the expression level of $M D H 2, I D H 2, S D H B$, $S D H D, M E 2$, and GOT2 genes. Second subline was obtained by selection of stable transfected clones with overexpression of dnIRE1 and has suppressed both protein kinase and endoribonuclease activities of this bifunctional sensing and signaling enzyme of 
endoplasmic reticulum stress. The expression level of the studied nuclear genes which encoded mitochondrial proteins in these cells was compared with cells transfected by vector (control 1). The subline, which overexpressed dnIRE1, was also used as control 2 for investigation of the effect of hypoxia condition on the expression level of that studied in cells with inhibited signaling enzyme IRE1 function. Clones were obtained by selection with $0.8 \mathrm{mg} / \mathrm{ml}$ geneticin (G418) and grown in the presence of this antibiotic at lower concentration $(0.4 \mathrm{mg} / \mathrm{ml})$.

In experiments with hypoxia culture plates with complete DMEM were exposed in a special chamber with 3\% oxygen, 92\% nitrogen, and 5\% carbon dioxide for $16 \mathrm{~h}$.

The suppression level of IRE1 and enzymatic activity in glioma cells that overexpress a dominant-negative construct of inositol requiring enzyme- 1 was estimated previously [30] by determining the expression level of XBP1 alternative splice variant (XBP1s), a key transcription factor in IRE1 signaling, using cells treated by tunicamycin (0.01 $\mathrm{mg} / \mathrm{ml}$ during $2 \mathrm{~h}$ ). Moreover, the proliferation rate of glioma cells with mutated IRE1 is 2-fold decreased [30]. Thus, the blockade of both kinase and endoribonuclease activity of signaling enzyme IRE1 has a significant effect on proliferation rate of glioma cells.

RNA isolation. Total RNA was extracted from glioma cells as described in [31]. The RNA pellets were washed with 75\% ethanol and dissolved in nuclease-free water. For additional purification RNA samples were re-precipitated with 95\% ethanol and re-dissolved again in nuclease-free water. RNA concentration and spectral characteristics were measured using NanoDrop Spectrophotometer.

Reverse transcription and quantitative PCR analysis. QuaniTect Reverse Transcription Kit (QIAGEN, Hilden, Germany) was used for cDNA synthesis as described previously [30]. The expression level of ME2, MDH2, IDH2, SDHB, SDHD, and GOT2 mRNA were measured in glioma cell line U87 and its subline (clone 1C5) by real-time quantitative polymerase chain reaction using "7900 HT Fast Real-Time PCR System” (Applied Biosystems) or "Mx 3000P QPCR" (Stratagene, USA) and Absolute qPCR SYBRGreen Mix (Thermo Fisher Scientific, ABgene House, Epsom, Surrey, UK). Polymerase chain reaction was performed in triplicate.

For amplification of the mitochondrial $\mathrm{NAD}^{+}-$ dependent malic enzyme 2(ME2; EC 1.1.1.38), also known as pyruvic-malic carboxylase, cDNA we used next primers: forward 5'-TTCTCTGTAACACCCGGCAT- $3^{\prime}$ and reverse 5'-TGGCCTTGTCTTCAGGTTCT-3'. The nucleotide sequences of these primers correspond to sequences 1695-1714 and 1910-1891 of human ME2 cDNA (GenBank accession number NM_002396). The size of amplified fragment is $216 \mathrm{bp}$.

The amplification of cDNA of the mitochondrial malate dehydrogenase 2 (MDH2; EC 1.1.1.37) was performed using forward primer $\left(5^{\prime}-\mathrm{CCT}\right.$ GTTCAACACCAATGCCA-3') and reverse primer (5'-GCCGAAGATTTTGTTGGGGT-3'). These oligonucleotides correspond to sequences 478-497 and 646-627 of human MDH2 cDNA (GenBank accession number NM_005918). The size of amplified fragment is $169 \mathrm{bp}$.

For amplification of the isocitrate dehydrogenase $2\left(\mathrm{NADP}^{+}\right)$, mitochondrial (IDH2; EC 1.1.1.42), also known as oxalosuccinate decarboxylase, cDNA we used forward 5'-TGCTTCCAGTATGCCATCCA- $3^{\prime}$ and reverse 5'-TCATAGTTCTTGCAGGCCCA $-3^{\prime}$ primers. The nucleotide sequences of these primers correspond to sequences 867-886 and 10991080 of human IDH2 cDNA (GenBank accession number NM_002168). The size of amplified fragment is $233 \mathrm{bp}$.

The amplification of the succinate dehydrogenase [ubiquinone] iron-sulfur subunit, mitochondrial (SDHB; EC 1.3.5.1), also known as succinate dehydrogenase complex iron sulfur subunit B, cDNA for real time RCR analysis was performed using two oligonucleotides primers: forward - 5'-AGAAACTGGACGGGCTCTAC-3' and reverse - 5'-TGTGGCAGCGGTATAGAGAG-3'. The nucleotide sequences of these primers correspond to sequences 684-703 and 884-865 of human SDHB cDNA (GenBank accession number NM_001161). The size of amplified fragment is $201 \mathrm{bp}$.

For amplification of the succinate dehydrogenase [ubiquinone] cytochrome b small subunit, mitochondrial (SDHD), also known as succinate-ubiquinone reductase membrane anchor subunit, cDNA we used forward 5'-ATACACTTGTCACCGAGCCA-3' and reverse 5'-CCCCAGTGACCATGAAGAGT-3' primers. The nucleotide sequences of these primers correspond to sequences 229-248 and 401-382 of human SDHD cDNA (GenBank accession number NM_003002). The size of amplified fragment is 173 bp.

The amplification of the glutamic-oxaloacetic transaminase 2, mitochondrial (GOT2; EC 2.6.1.1), also known as kynurenine aminotransferase IV 
(KAT4) and aspartate aminotransferase, mitochondrial (mitAAT) cDNA into real time RCR analysis was performed using two oligonucleotides primers: forward - 5'-AACTAGCCCTGGGTGAGAAC-3' and reverse - 5'-CCTGTGAAGTCAAAACCGCA-3'. The nucleotide sequences of these primers correspond to sequences $461-480$ and 707-688 of human GOT2 cDNA (GenBank accession number NM_002080). The size of amplified fragment is 247 bp.

For amplification of $\beta$-actin (ACTB) cDNA was used forward - 5'-GGACTTCGAGCAAGAGATGG-3' and reverse - 5'-AGCACTGTGTTGGCGTACAG $-3^{\prime}$ primers. These primers nucleotide sequences correspond to 747-766 and 980-961 of human ACTB cDNA (GenBank accession number NM_001101). The size of amplified fragment is $234 \mathrm{bp}$. The expression of $\beta$-actin mRNA was used as control of analyzed RNA quantity. The primers were received from Sigma-Aldrich (St. Louis, MO, USA).

Quality of amplification products was analyzed by melting curves and by electrophoresis using $2 \%$ agarose gel. An analysis of quantitative PCR was performed using special computer program "Differential expression calculator". The values of ME2, MDH2, IDH2, SDHB, SDHD, and GOT2 mRNA expressions were normalized to the expression of $\beta$-actin mRNA and represented as percent of control 1 (100\%).

Statistical analysis. All values are expressed as mean \pm SEM from triplicate measurements performed in 4 independent experiments. Statistical analysis was performed according to Student's $t$-test using Excel program as described previously [32].

\section{Results and Discussion}

We have studied the effect of hypoxia on the expression of nuclear genes encoding mitochondrial proteins ME2, MDH2, IDH2, SDHB, SDHD, and GOT2 in two sublines of U87 glioma cells in relation to inhibition of IRE1 signaling enzyme, which is a major component of the unfolded protein response. It was shown that in control glioma cells (transfected by empty vector) hypoxia significantly down-regulates (-40\%) the expression of nuclear gene for mitochondrial malic enzyme 2, that catalyzes the oxidative decarboxylation of malate to pyruvate (Fig. 1). Moreover, in cells without functional activity of IRE1 signaling enzyme the expression of this gene is also decreased by hypoxia (-23\%). Furthermore, the inhibition of IRE1 signaling enzyme function in U87 glioma cells by dnIRE1 leads to significant down-regulation of ME2 gene expression (-60\%) in normoxic conditions in comparison with the control glioma cells (Fig. 1).

As shown in Fig. 2, the expression level of malate dehydrogenase $2(\mathrm{MDH} 2)$ gene is also decreased in control glioma cells treated by hypoxia $(-17 \%)$, but in glioma cells with suppressed activity of IRE1 signaling the enzyme hypoxia does not significantly change the expression level of this gene. We also studied the effect of IRE1 inhibition on the expression of this gene in normoxic conditions. It was also shown that inhibition of IRE1 signaling enzyme has strongly decreased (-48\%) the expression level of MDH2 mRNA in glioma cells in normoxic conditions as compared to control glioma cells (Fig. 2).

Investigation of the expression of $I D H 2$ gene, which encodes mitochondrial isocitrate dehydrogenase $2\left(\mathrm{NADP}^{+}\right)$enzyme, has shown that hypoxia does not affect this gene expression in control glioma cells, but inhibition of IRE1 signaling enzyme function in U87 glioma cells by dnIRE1 leads to significant down-regulation of IDH2 gene expression (-50\%) by hypoxia (Fig. 3). Thus, the inhibition of IRE1 introduces sensitivity of this gene expression to hypoxia in U87 glioma cells. Next we studied the effect of inhibition of IRE1 signaling enzyme on the expression of $I D H 2$ gene in normoxic conditions. As shown in Fig. 3, the level of IDH2 mRNA expression is strongly up-regulated (+262\%) in glioma cells without IRE1 signaling enzyme function in comparison with the control glioma cells.

We next investigated the effect of hypoxia on the expression of succinate dehydrogenase [ubiquinone] iron-sulfur subunit ( $S D H B$ ) gene in control U87 glioma cells and cells with inhibited function of signaling enzyme IRE1. As shown in Fig. 4, the expression level of SDHB mRNA is down-regulated $(-37 \%)$ in control glioma cells treated by hypoxia. In cells with suppressed function of IRE1 signaling enzyme hypoxia the level of $S D H B$ gene expression also decreases in comparison with the control 2 glioma cells, but the effect of hypoxia in these cells was significantly reduced (-16\%). Furthermore, the expression of this gene is also down-regulated in normoxic conditions by inhibition of signaling enzyme IRE1 function (-32\%) as compared to control glioma cells.

It was also shown that hypoxia introduces small but statistically significant decreases of the expres- 


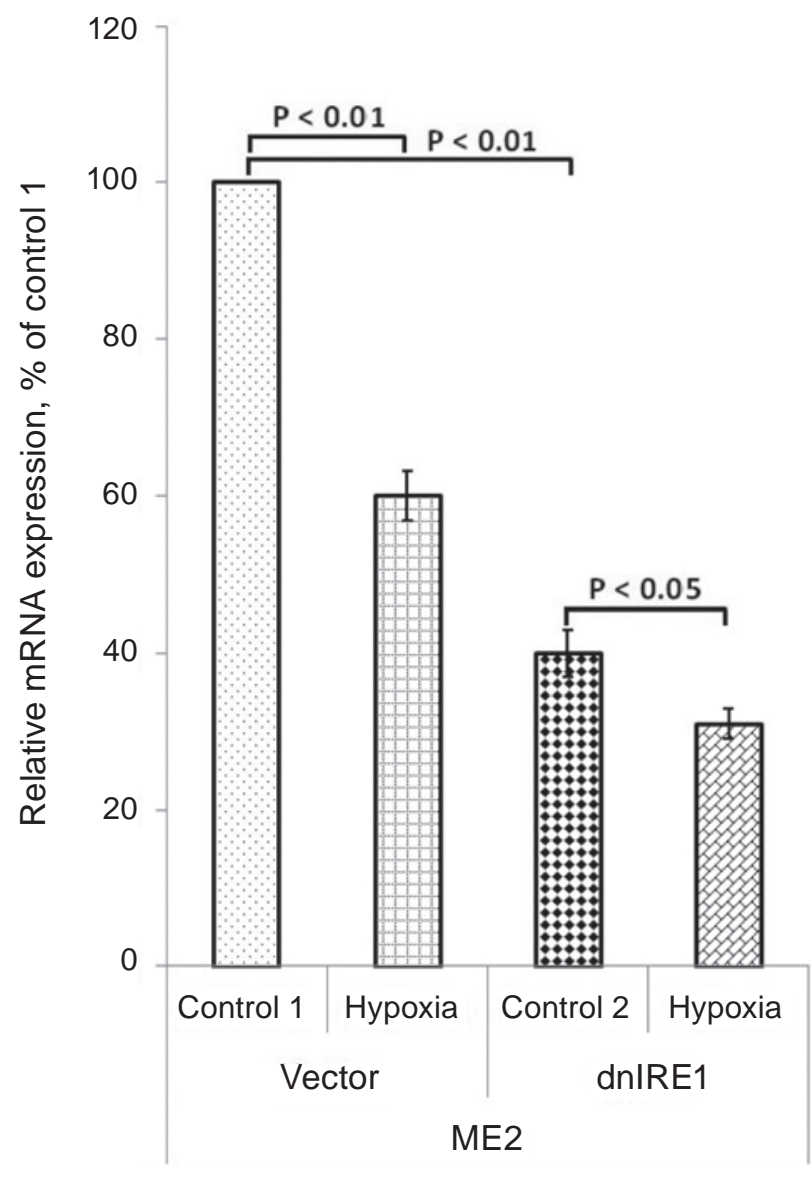

Fig. 1. Effect of hypoxia (3\% oxygen -16 h) on the expression level of mitochondrial malate dehydrogenase 2 (ME2)mRNA in control U87 glioma cells stably transfected with vector (Vector) and cells with inhibited function of signaling enzyme IRE1 (dnIRE1) measured by qPCR. Values of ME2 $m R N A$ expressions were normalized to $\beta$-actin $m R N A$ and represented as percent of control 1 (100\%); mean \pm SEM; $n=4$

sion of succinate dehydrogenase [ubiquinone] cytochrome $b$ small subunit gene (-14\%) in control U87 glioma cells as compared to control 1 (Fig. 5). At the same time, the inhibition of IRE1 signaling enzyme function by dnIRE1 eliminates hypoxic regulation of this gene expression in comparison with the control 2 glioma cells. As shown in Fig. 5, the expression of SDHD gene in normoxic conditions is downregulated (-32\%) in cells with IRE1 knockdown as compared to control glioma cells.

Investigation of GOT2 gene, which encoded mitochondrial glutamic-oxaloacetic transaminase 2, has shown significant down-regulation by hypoxia in control glioma cells as compared to control cells (-46\%; Fig. 6). Furthermore, hypoxia also decreases the expression level of this gene (-36\%) in cells with inhibited IRE1 signaling enzyme function. Therefore, the inhibition of IRE1 slightly decreases the effect of hypoxia on the expression of GOT2 gene in U87 glioma cells. Moreover, the inhibition of IRE1 signaling enzyme function in glioma cells by dnIRE1 leads to significant down-regulation (-38\%) of this gene expression in normoxic conditions (Fig. 6). Thus, hypoxia and inhibition of IRE1 have unidirectional and approximately similar effects on the expression of GOT2 gene in U87 glioma cells in the normoxic and hypoxic conditions.

Therefore, the effect of hypoxia on the expression level of nuclear genes encoding all studied

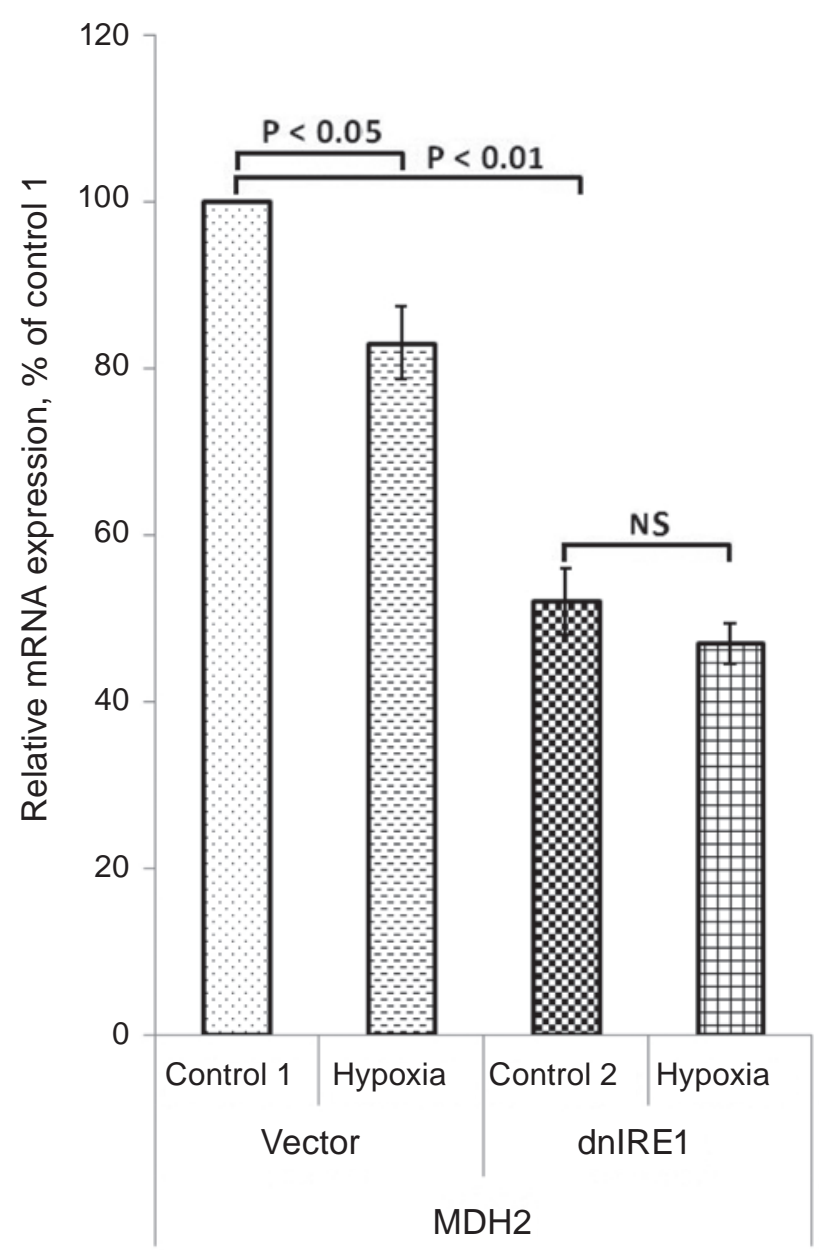

Fig. 2. Effect of hypoxia (3\% oxygen -16 h) on the expression level of malate dehydrogenase $2(\mathrm{MDH} 2)$ mRNA in control U87 glioma cells stably transfected with vector (Vector) and cells without signaling enzyme IRE1 function (dnIRE1) measured by qPCR. Values of MDH2 $\mathrm{mRNA}$ expressions were normalized to $\beta$-actin $m R N A$ expression and represented as percent of control 1 (100\%); mean \pm SEM; $n=4$ 


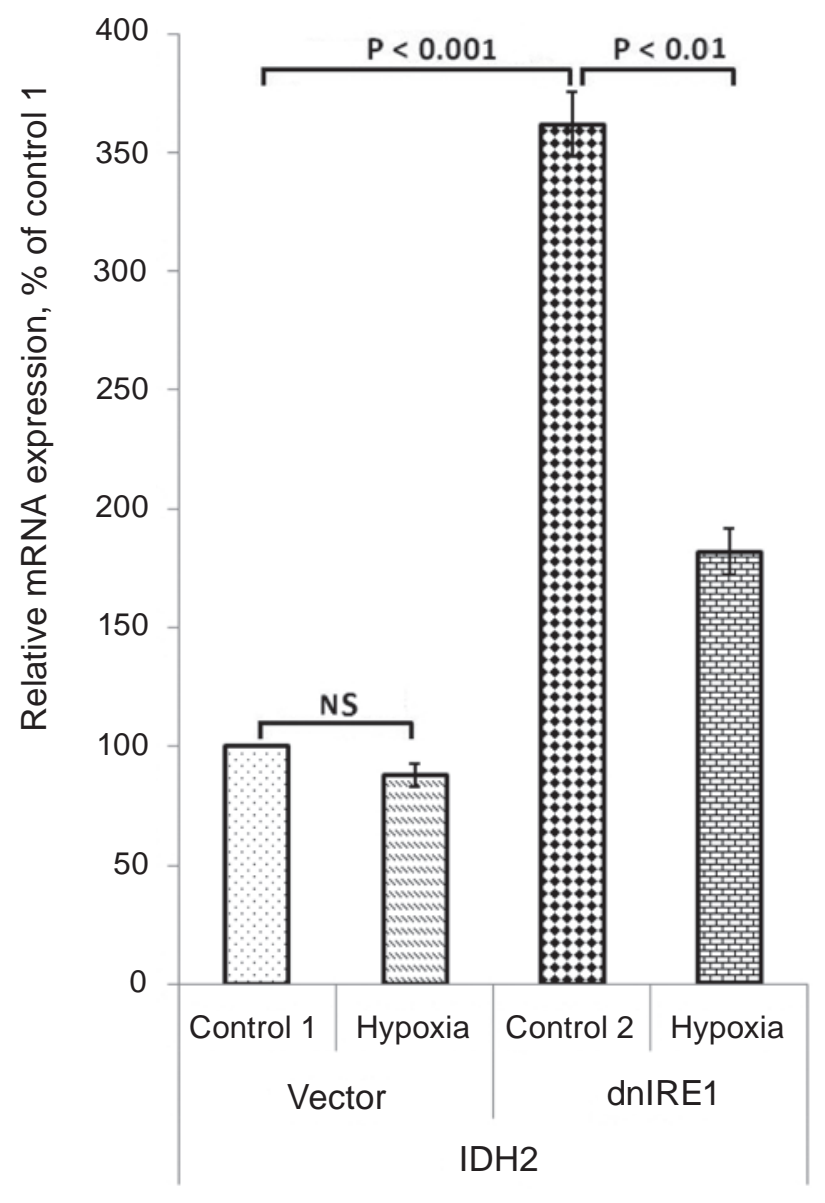

Fig. 3. Effect of hypoxia (3\% oxygen -16 h) on the expression level of mitochondrial isocitrate dehydrogenase 2 (NADP+; IDH2) mRNA in control U87 glioma cells stably transfected with vector (Vector) and cells without function of signaling enzyme IRE1 (dnIRE1) measured by qPCR. Values of IDH2 $\mathrm{mRNA}$ expressions were normalized to $\beta$-actin $m R N A$ expression and represented as percent of control 1 $(100 \%) ;$ mean $\pm S E M ; n=4$

mitochondrial proteins depends on IRE1 signaling enzyme function, because the inhibition of IRE1 significantly modifies hypoxic regulation of these gene expressions: eliminates effect of hypoxia on the expression of $M D H 2$ and SDHD genes (Fig. 2 and 5) and introduces sensitivity to hypoxia of $I D H 2$ gene (Fig. 3). Moreover, as shown in Fig. 7, the effect of hypoxia on the expression level of ME2, SDHB, and GOT2 mRNA in glioma cells is significantly suppressed by the inhibition of IRE1 signaling enzyme function.

In this study we have shown that hypoxia significantly suppresses the expression of most studied nuclear genes encoding mitochondrial proteins, key mitochondrial enzymes in U87 glioma cells, and that the inhibition of IRE1 signaling enzyme function modifies the effect of hypoxia on the expression level of these genes in gene specific manner like many other previously studied genes, including nuclear genes for mitochondrial proteins [5, 8, 33-35]. It is possible that hypoxia suppresses oxidative phosphorylation in mitochondria and as a consequence down-regulation of ME2, $M D H 2, S D H B, S D H D$, and GOT2 genes expression in glioma cells with native IRE1 signaling enzyme.

We have also shown that inhibition of IRE1 signaling enzyme function down-regulates the ex-

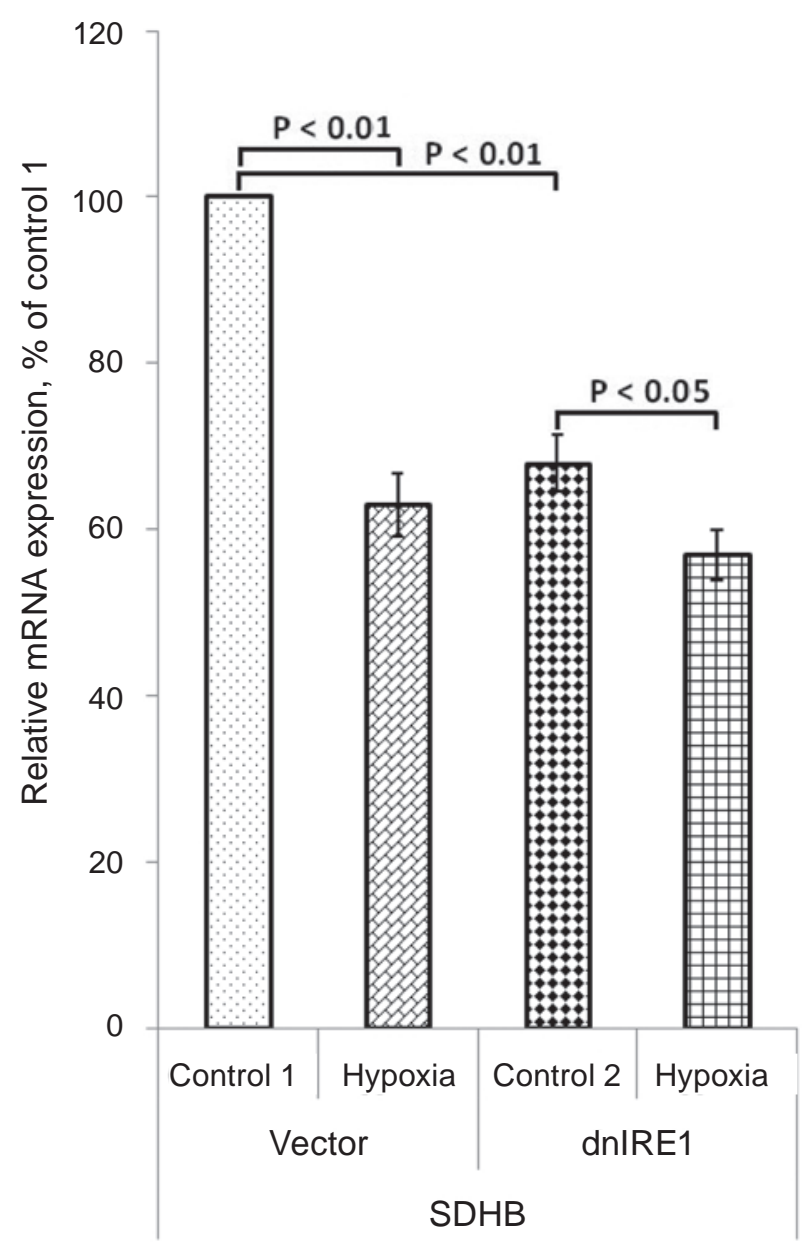

Fig. 4. Effect of hypoxia (3\% oxygen -16 h) on the expression level of succinate dehydrogenase [ubiquinone] iron-sulfur subunit (SDHB) $m R N A$ in control U87 glioma cells stably transfected with vector (Vector) and cells without function of signaling enzyme IRE1 (dnIRE1) measured by qPCR. Values of SDHB mRNA expressions were normalized to $\beta$-actin $m R N A$ expression and represented as percent of control 1 (100\%); mean $\pm S E M ; n=4$ 


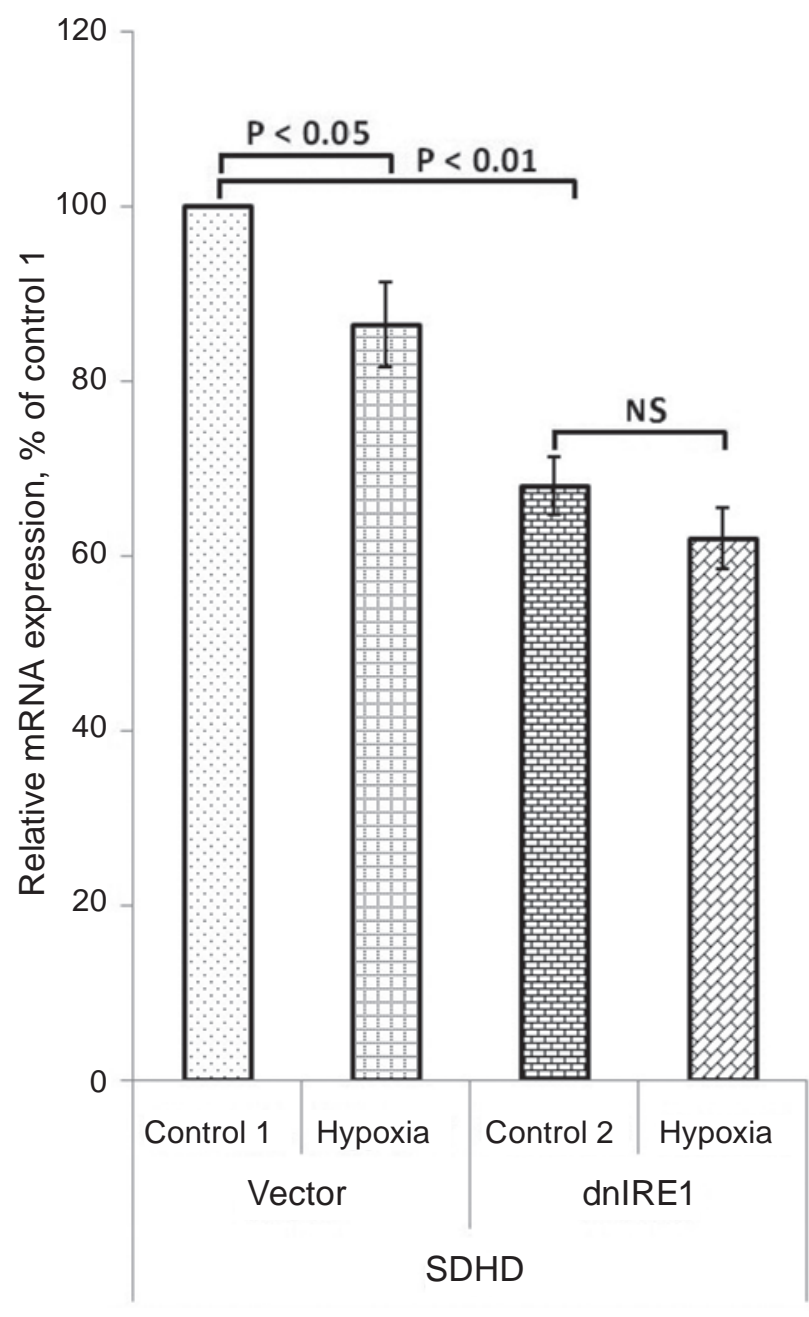

Fig. 5. Effect of hypoxia (3\% oxygen - 16 h) on the expression level of succinate dehydrogenase [ubiquinone] cytochrome b small subunit (SDHD) mRNA in control U87 glioma cells stably transfected with vector (Vector) and cells without function of signaling enzyme IRE1 (dnIRE1) measured by qPCR. Values of SDHD mRNA expressions were normalized to $\beta$-actin mRNA expression and represented as percent of control 1 (100\%); mean \pm SEM; $n=4$

pression level of all studied nuclear genes for mitochondrial proteins except for IDH2 gene and this data correlated well with suppression of proliferation of these glioma cells [14, 15], because almost all of these genes are highly expressed or mutated in many solid tumors and their knockdown inhibits cell proliferation and induces cell death [18-22, 26, 27]. Induction of $I D H 2$ gene expression in glioma cells with inhibited IRE1 signaling enzyme argues with the data that IDH2 plays an essential role protecting cells against oxidative stress-induced damage and that this enzyme deficiency leads to mitochondrial dysfunction and production of reactive oxygen species in cancer cells [24].

Moreover, we have also shown that the inhibition of IRE1 signaling enzyme function modifies the hypoxic regulation of these gene expressions in glioma cells except for GOT2 gene. Thus, the effect of hypoxia on the expression level of ME2 and $S D H B$ genes was significantly lesser in glioma cells without IRE1 signaling enzyme function as compared to control glioma cells. At the same time the inhibition of the function activity of IRE1 signaling enzyme completely eliminates the hypoxic regulation of expression of $M D H 2$ and SDHD genes in glioma cells, but introduces sensitivity to hypoxia of the expres-

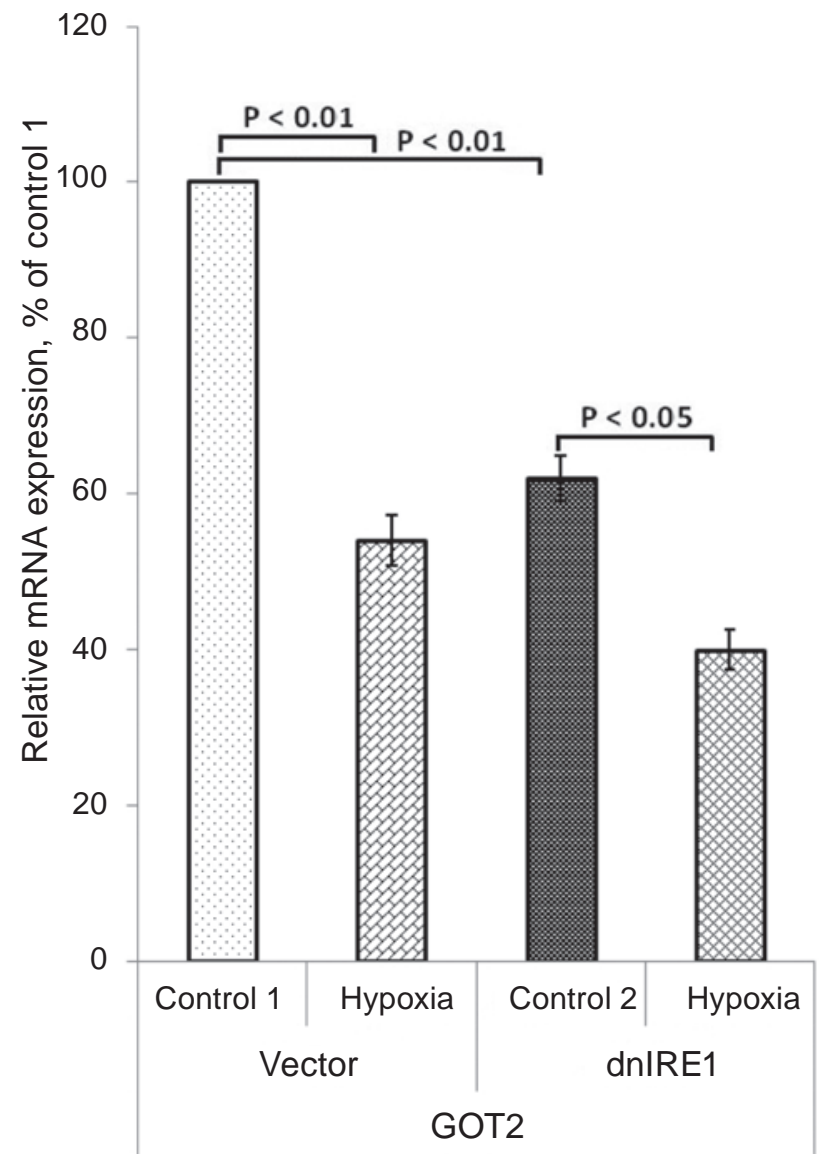

Fig. 6. Effect of hypoxia (3\% oxygen -16 h) on the expression level of mitochondrial glutamic-oxaloacetic transaminase 2 (GOT2) $m R N A$ in control U87 glioma cells stably transfected with empty vector (Vector) and cells without function of signaling enzyme IRE1 (dnIRE1) measured by qPCR. Values of GOT2 mRNA expressions were normalized to $\beta$-actin mRNA expression and represented as percent of control 1 (100\%); mean $\pm S E M ; n=4$ 


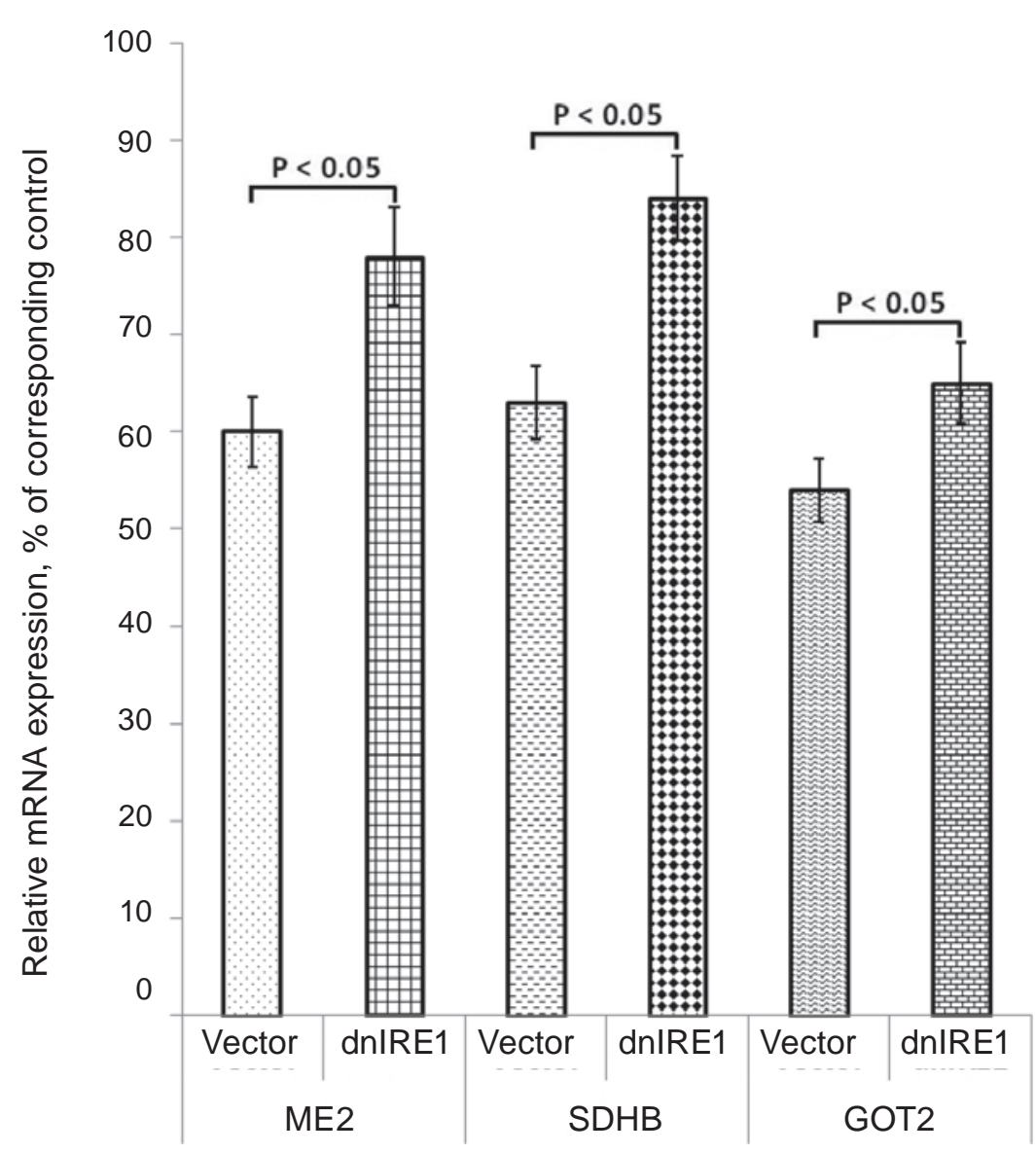

Fig. 7. Effect of hypoxia (3\% oxygen - 16 h) on the expression level of ME2, SDHB, and GOT2 mRNA in control U87 glioma cells stably transfected with empty vector (Vector) and in cells without function of signaling enzyme IRE1 (dnIRE1) measured by qPCR. Values of ME2, SDHB, and GOT2 $\mathrm{mRNA}$ expressions were normalized to $\beta$-actin mRNA expression and represented as percent of corresponding control (100\%); mean $\pm S E M ; n=4$

sion of $I D H 2$ gene. It is possible that hypoxic regulation of ME2, MDH2, GOT2, SDHD, SDHB, and $I D H 2$ genes is realized through multiple signaling pathways, and IRE1 plays an ancillary role. Thus, our results agree with data of $[16-21,26]$ that the suppression of IRE1 signaling enzyme function significantly decreases the glioma cell proliferation and that reduced level of ME2, MDH2, GOT2, SDHB, and SDHD genes expression can contribute to regulation of cell death processes and to suppression of glioma cell proliferation upon inhibition of IRE1mediated endoplasmic reticulum stress signaling. However, the functional significance of changes in ME2, $M D H 2$, GOT2, SDHD, SDHB, and IDH2 gene expressions and prospective studies are still to be confirmed. 


\section{ВПЛИВ ГІПОКСІЇ НА ЕКСПРЕСІЮ ЯДЕРНИХ ГЕНІВ, ЩО КОДУЮТЬ МІТОХОНДРІАЛЬНІ ПРОТЕЇНИ, В КЛІТИНАХ ГЛІОМИ ЛІНІї U87}

\author{
О. Г. Мінченко , О. О. Рябовол 1 , \\ Д. О. Цимбал ${ }^{1}$, Д. О. Мінченко, \\ О. О. Ратушна
}

\author{
${ }^{1}$ Інститут біохімії ім. О. В. Палладіна \\ Національної академії наук України, Київ; \\ e-mail: ominchenko@yahoo.com; \\ ${ }^{2}$ Національний медичний університет \\ ім. О. О. Богомольця, Київ, Україна
}

Нами досліджувався вплив гіпоксії на експресію ядерних генів, що кодують мітохондріальні протеїни, у клітинах гліоми лінії U87 за умов пригнічення IRE1 (inositolrequiring-enzyme-1), який $\epsilon$ центральним медіатором стресу ендоплазматичного ретикулума і контролює процеси проліферації та росту пухлин. Показано, що гіпоксія знижувала експресію генів малатдегідрогенази 2 (MDH2), малікензиму 2 (ME2), мітохондріальної аспартатамінотрансферази (GOT2) та субодиниці В сукцинатдегідрогенази (SDHB) у контрольних (трансфікованих вектором без вставки) клітин гліоми геноспецифічно. У той самий час рівень експресії генів $\mathrm{NADP}^{+}$-залежної мітохондріальної ізоцитратдегідрогенази 2 (IDH2) та субодиниці D сукцинатдегідрогенази $(S D H D)$ у цих клітинах в умовах гіпоксії істотно не змінювався. Встановлено також, що пригнічення функції сигнального ензиму IRE1 у клітинах гліоми лінії U87 послаблювало ефект гіпоксії на експресію генів ME2, GOT2 і SDHB, а також робило чутливим до гіпоксії ген IDH2. Більше того, експресія всіх досліджених генів була геноспецифічно залежною від опосередкованого IRE1 сигналювання стресу ендоплазматичного ретикулума, оскільки пригнічення IRE1 істотно знижувало їх експресію в умовах нормоксії, за винятком гена IDH2, рівень експресії якого різко підвищувався. Таким чином, зміни рівня експресії ядерних генів, що кодують протеїни ME2, MDH2, IDH2, SDHB, SDHD та GOT2, можливо віддзеркалюють метаболічне репрограмування мітохондрій за гіпоксії та стресу ендоплазматичного ретикулума, опосередкованого IRE1 сигнальним шляхом, і корелюють зі зниженням проліферації клітин гліоми за умов пригнічення функції ензиму IRE1.

К л ю ч о в і с лов а: гіпоксія, експресія мРНК, мітохондріальні протеїни, пригнічення IRE1, клітини гліоми лінії U87.

\section{ВЛИЯНИЕ ГИПОКСИИ}

НА ЭКСПРЕССИЮ ЯДЕРНЫХ

ГЕНОВ, КОДИРУЮЩИХ

МИТОХОНДРИАЛЬНЫЕ ПРОТЕИНЫ

В КЛЕТКАХ ГЛИОМЫ ЛИНИИ U87

О. Г. Минченко ${ }^{1}$ О. О. Рябовол ${ }^{1}$,

Д. О. Цымбал, Д. О. Минченко,

О. О. Ратушна ${ }^{1}$

${ }^{1}$ Институт биохимии им. А. В. Палладина Национальной академии наук Украины, Киев; e-mail: ominchenko@yahoo.com;

${ }^{2}$ Национальный медицинский университет им. А. А. Богомольца, Киев, Украина

Нами изучалось влияние гипоксии на экспрессию ядерных генов, кодирующих митохондриальные протеины, в клетках глиомы линии U87 при угнетении IRE1 (inositol requiring enzyme-1), который является центральным медиатором стресса эндоплазматического ретикулума и контролирует процессы пролиферации и роста опухолей. Показано, что гипоксия снижала экспрессию генов малатдегидрогеназы 2 (MDH2), маликэнзима 2 (ME2), митохондриальной аспартат аминотрансферазы (GOT2) и субъединицы В сукцинатдегидрогеназы (SDHB) в контрольных (трансфецированных вектором без вставки) клетках глиомы геноспецифически. В то же время, уровень экспрессии генов митохондриальной $\mathrm{NADP}^{+}$-зависимой изоцитратдегидрогеназы 2 (IDH2) и субъединицы D сукцинатдегидрогеназы (SDHD) в этих клетках существенно не изменялся при гипоксии. Установлено также, что угнетение функции сигнального энзима IRE1 в клетках глиомы линии U87 снижало эффект гипоксии на экспрессию генов $M E 2, G O T 2$ и $S D H B$, а также делает чувствительным к гипоксии ген IDH2. Более того, экспрессия всех исследованных генов геноспецифически зависила от опосредованного IRE1 сигналинга стресса эндоплазматичного ретикулума, поскольку угнетение IRE1 существенно снижало их экспрессию при нормоксии, за исключением гена IDH2, уровень экспрессии которого рез- 
ко увеличивался. Таким образом, изменения уровня экспрессии ядерных генов, кодирующих протеины ME2, MDH2, IDH2, SDHB, SDHD и GOT2, возможно отображают метаболическое репрограммирование митохондрий при гипоксии и стрессе эндоплазматического ретикулума, опосредованного IRE1 сигнальным путем, и коррелируют со снижением роста глиомы при угнетении функции энзима IRE1.

К л ю че в ы е с ло в а: гипоксия, экспрессия мРНК, митохондриальные протеины, угнетение IRE1, клетки глиомы линии U87.

\section{References}

1. Lee WT, St John J. The control of mitochondrial DNA replication during development and tumorigenesis. Ann N Y Acad Sci. 2015; 1350: 95-106.

2. Cobanoglu B, Ceyran AB, Simsek M, Şenol S. Immunohistochemical analysis of Bax and AIF in colorectal tumors. Int J Clin Exp Med. 2015; 8(9): 16071-16076.

3. Zhdanov DD, Fahmi T, Wang X, Apostolov EO, Sokolov NN, Javadov S, Basnakian AG. Regulation of Apoptotic Endonucleases by EndoG. DNA Cell Biol. 2015; 34(5): 316-326.

4. Zhao H, Wang C, Lu B, Zhou Z, Jin Y, Wang Z, Zheng L, Liu K, Luo T, Zhu D, Chi G, Luo Y, Ge P. Pristimerin triggers AIF-dependent programmed necrosis in glioma cells via activation of JNK. Cancer Lett. 2016; 374(1): 136-148.

5. Minchenko OH, Tsymbal DO, Minchenko DO, Riabovol OO, Ratushna OO, Karbovskyi LL. Hypoxic regulation of the expressions of cell proliferation related genes in U87 glioma cells upon inhibition of IRE1 signaling enzyme. $U \mathrm{kr}$ Biochem J. 2016; 88(1): 11-21.

6. Linkowska K, Jawień A, Marszałek A, Malyarchuk BA, Tońska K, Bartnik E, Skonieczna K, Grzybowski T. Mitochondrial DNA Polymerase $\gamma$ Mutations and Their Implications in mtDNA Alterations in Colorectal Cancer. Ann Hum Genet. 2015; 79(5): 320-328.

7. Swan EJ, Maxwell AP, McKnight AJ. Distinct methylation patterns in genes that affect mitochondrial function are associated with kidney disease in blood-derived DNA from individuals with Type 1 diabetes. Diabet Med. 2015; 32(8): 1110-1115.
8. Kryvdiuk IV, Minchenko DO, Hlushchak NA, Ratushna OO, Karbovskyi LL, Minchenko OH. Inhibition of IRE1 modifies the hypoxic regulation of GADD family gene expressions in U87 glioma cells. Ukr Biochem J. 2015; 87(6): 36-51.

9. Lenihan CR, Taylor CT. The impact of hypoxia on cell death pathways. Biochem Soc Trans. 2013; 41(2): 657-663.

10. Zhang X, Bian X, Kong J. The proapoptotic protein BNIP3 interacts with VDAC to induce mitochondrial release of endonuclease G. PLoS One. 2014; 9(12): e113642.

11. Manié SN, Lebeau J, Chevet E. Cellular mechanisms of endoplasmic reticulum stress signaling in health and disease. 3. Orchestrating the unfolded protein response in oncogenesis: an update. Am J Physiol Cell Physiol. 2014; 307(10): C901-C907.

12. Hetz C, Chevet E, Harding HP. Targeting the unfolded protein response in disease. Nat Rev Drug Discov. 2013; 12(9): 703-719.

13. Wang S, Kaufman RJ. The impact of the unfolded protein response on human disease. J Cell Biol. 2012; 197(7): 857-867.

14. Auf G, Jabouille A, Guérit S, Pineau R, Delugin M, Bouchecareilh M, Magnin N, Favereaux A, Maitre M, Gaiser $\mathrm{T}$, von Deimling A, Czabanka M, Vajkoczy P, Chevet E, Bikfalvi A, Moenner M. Inositol-requiring enzyme 1alpha is a key regulator of angiogenesis and invasion in malignant glioma. Proc Natl Acad Sci USA. 2010; 107(35): 15553-15558.

15. Auf G, Jabouille A, Delugin M, Guérit S, Pineau R, North S, Platonova N, Maitre M, Favereaux A, Vajkoczy P, Seno M, Bikfalvi A, Minchenko D, Minchenko O, Moenner M. High epiregulin expression in human U87 glioma cells relies on IRE1 $\alpha$ and promotes autocrine growth through EGF receptor. BMC Cancer. 2013; 13: 597.

16. Jiang P, Du W, Mancuso A, Wellen KE, Yang X. Reciprocal regulation of p53 and malic enzymes modulates metabolism and senescence. Nature. 2013; 493(7434): 689-693.

17. Ren JG, Seth P, Everett P, Clish CB, Sukhatme VP. Induction of erythroid differentiation in human erythroleukemia cells by depletion of malic enzyme 2. PLoS One. 2010; 5(9). pii: e12520. 
18. Ren JG, Seth P, Clish CB, Lorkiewicz PK, Higashi RM, Lane AN, Fan TW, Sukhatme VP. Knockdown of malic enzyme 2 suppresses lung tumor growth, induces differentiation and impacts PI3K/AKT signaling. Sci Rep. 2014; 4: 5414.

19. Hsieh JY, Li SY, Tsai WC, Liu JH, Lin CL, Liu GY, Hung HC. A small-molecule inhibitor suppresses the tumor-associated mitochondrial NAD(P) $)^{+}$-dependent malic enzyme (ME2) and induces cellular senescence. Oncotarget. 2015; 6(24): 20084-20098.

20. Yang H, Zhou L, Shi Q, Zhao Y, Lin H, Zhang M, Zhao S, Yang Y, Ling ZQ, Guan KL, Xiong Y, Ye D. SIRT3-dependent GOT2 acetylation status affects the malate-aspartate NADH shuttle activity and pancreatic tumor growth. EMBO J. 2015; 34(8): 1110-1125.

21. Eleftheriadis T, Pissas G, Antoniadi G, Liakopoulos V, Stefanidis I. Malate dehydrogenase-2 inhibitor LW6 promotes metabolic adaptations and reduces proliferation and apoptosis in activated human T-cells. Exp Ther Med. 2015; 10(5): 1959-1966.

22. Viswanath P, Chaumeil MM, Ronen SM. Molecular Imaging of Metabolic Reprograming in Mutant IDH Cells. Front Oncol. 2016; 6: 60.

23. Flavahan WA, Drier Y, Liau BB, Gillespie SM, Venteicher AS, Stemmer-Rachamimov AO, Suvà ML, Bernstein BE. Insulator dysfunction and oncogene activation in IDH mutant gliomas. Nature. 2016; 529(7584): 110-114.

24. Park JB, Nagar H, Choi S, Jung SB, Kim HW, Kang SK, Lee JW, Lee JH, Park JW, Irani K, Jeon BH, Song HJ, Kim CS. IDH2 deficiency impairs mitochondrial function in endothelial cells and endothelium-dependent vasomotor function. Free Radic Biol Med. 2016; 94: 36-46.

25. Agaimy A. Succinate dehydrogenase (SDH)deficient renal cell carcinoma. Pathologe. 2016; 37(2): 144-152.

26. Miettinen M. Succinate dehydrogenase-deficient tumors--a novel mechanism of tumor formation. Duodecim. 2015; 131(22): 2149-2156.
27. Scholz SL, Horn S, Murali R, Möller I, Sucker A, Sondermann W, Stiller M, Schilling B, Livingstone E, Zimmer L, Reis H, Metz CH, Zeschnigk M, Paschen A, Steuhl KP, Schadendorf D, Westekemper H, Griewank KG. Analysis of SDHD promoter mutations in various types of melanoma. Oncotarget. 2015; 6(28): 25868-25882.

28. Saxena N, Maio N, Crooks DR, Ricketts CJ, Yang Y, Wei MH, Fan TW, Lane AN, Sourbier C, Singh A, Killian JK, Meltzer PS, Vocke CD, Rouault TA, Linehan WM. SDHB-Deficient Cancers: The Role of Mutations That Impair Iron Sulfur Cluster Delivery. J Natl Cancer Inst. 2016; 108(1): djv287.

29. Denko NC. Hypoxia, HIF1 and glucose metabolism in the solid tumour. Nat Rev Cancer. 2008; 8(9): 705-713.

30. Minchenko DO, Danilovskyi SV, Kryvdiuk IV, Bakalets TV, Lypova NM, Karbovsky LL, Minchenko OH. Inhibition of ERN1 modifies the hypoxic regulation of the expression of TP53related genes in U87 glioma cells. Endoplasm Reticul Stress Dis. 2014; 1(1): 18-26.

31. Minchenko O, Opentanova I, Minchenko D, Ogura T, Esumi H. Hypoxia induces transcription of 6-phosphofructo-2-kinase/fructose-2,6biphosphatase-4 gene via hypoxia-inducible factor-1alpha activation. FEBS Lett. 2004; 576(12): 14-20.

32. Bochkov VN, Philippova M, Oskolkova O, Kadl A, Furnkranz A, Karabeg E, Afonyushkin T, Gruber F, Breuss J, Minchenko A, Mechtcheriakova D, Hohensinner P, Rychli K, Wojta J, Resink T, Erne P, Binder BR, Leitinger N. Oxidized phospholipids stimulate angiogenesis via autocrine mechanisms, implicating a novel role for lipid oxidation in the evolution of atherosclerotic lesions. Circ Res. 2006; 99(8): 900-908.

33. Minchenko DO, Karbovskyi LL, Danilovskyi SV, Moenner M, Minchenko OH. Effect of hypoxia and glutamine or glucose deprivation on the expression of retinoblastoma and retinoblastoma- 
related genes in ERN1 knockdown glioma U87 cell line. Am J Mol Biol. 2012; 2(1): 21-31.

34. Minchenko DO, Kharkova AP, Karbovskyi LL, Minchenko $\mathrm{OH}$. Expression of insulin-like growth factor binding protein genes and its hypoxic regulation in U87 glioma cells depends on ERN1 mediated signaling pathway of endoplasmic reticulum stress. Endocr Regul. 2015; 49(2): 73-83.
35. Minchenko OH, Kharkova AP, Minchenko DO, Karbovskyi LL. Effect of hypoxia on the expression of IGFBP6, IGFBP7, NOV, CYR61, WISP1, and WISP2 genes in U87 glioma cells depends on ERN1 mediated signaling pathway of endoplasmic reticulum stress. $U \mathrm{kr}$ Biochem $\mathrm{J}$. 2015; 87(6): 52-63.

Received 10.05.2016 